\title{
RIEMANN SUMS FOR SELF-ADJOINT OPERATORS
}

\author{
J. Rooin, A. Alikhani And M. S. MosLehian
}

Abstract. This paper focuses on Riemann sums for the functional calculus of bounded selfadjoint operaors. We first obtain some monotonicity properties of operator convex functions. Using these results we then refine an operator Hermite-Hadamard type inequality. Finally we extend the Alzer and Bennet inequalities to operators on Hilbert spaces.

Mathematics subject classification (2010): 47A63, 15A42, 47A30.

Keywords and phrases: Hermite-Hadamard inequality, operator convex function, Alzer inequality, Bennet inequality, operator inequality.

\section{REFERENCES}

[1] Nieuw Archief Voor Wiskunde, 3rd series, XXIII, no. 3, November 1975, pp. 254-257.

[2] S. Abramovich, J. Barić, M. Matić and J. PeČarić, On van de Lune-Alzer's inequality, J. Math. Inequal. 1 (2007), no. 4, 563-587.

[3] H. Alzer, On an inequality of H. Minc and L. Sathre, J. Math. Anal. Appl. 179 (1993), 396-402.

[4] G. Bennet, Lower bounds for matrices, II, Canad. J. Math. 44 (1992), no. 1, 54-74.

[5] J.-C. BOURIN AND E.-Y. LEE, Unitary orbits of Hermitian operators with convex and concave functions, Bull. London Math. Soc. 44 (2012) 1085-1102.

[6] C.-P. ChEN AND F. QI, Extension of an inequality of H. Alzer for negative powers, Tamkang. J. Math. 36 (2005), no. 1, 69-72.

[7] C.-P. Chen, F. QI, P. CERone AND S. S. DRAGomir, Monotonicity of sequences involving convex and concave functions, Math. Inequal. Appl. 6 (2003), no. 2, 229-239.

[8] S. S. DraGOMIR, Hermite-Hadamard's type inequalities for operator convex functions, Appl. Math. Comput. 218 (2011), no. 3, 766-772.

[9] N. Elezović And J. PeČArić, On Alzer's inequality, J. Math. Anal. Appl. 223 (1998), 366-369.

[10] T. Furuta, J. Mićić Hot, J. E. PeČARIć And Y. Seo, Mond-Pečarić Method in Operator Inequalities, Element, Zagreb, 2005.

[11] J.-C. KUANG, Some extensions and refinements of Minc-Sathre inequality, Math. Gaz. 83 (1999), $123-127$.

[12] H. Minc And L. SAthre, Some inequalities involving $(r !)^{\frac{1}{r}}$, Proc. Edinburgh Math. Soc. 14 (1964/65), 41-46.

[13] M. S. Moslehian, Matrix Hermite-Hadamard's type inequalities, Houston J. Math. 39 (2013), no. 1, $177-189$.

[14] M. S. Moslehian AND H. NAJAFI, An extension of the Lowner-Heinz inequality, Linear Algebra Appl. 437 (2012), no. 9, 2359-2365.

[15] F. QI AND B.-N. GUO, Monotonicity of sequences involving convex function and sequence, Math. Inequal. Appl. 9 (2006), no. 2, 247-254.

[16] J. Rooin, An extension of Alzer's inequality via convexity with applications, MIA 2008 Conference, 8-14 June 2008, Trogir-Split, Croatia.

[17] J. SÁnDOR, On an inequality of Alzer, J. Math. Anal. Appl. 192 (1995), 1034-1035. 